early breast cancer in itself produces psychiatric morbidity.

We thank the Cancer Research Council for financial support. We also thank Ruth Sutton and Stella Khenia for their help with the preparation of data for analysis, Roger A'Hern for statistical advice, and Philippa Male for help with interviewing and rerating tape recordings. Finally, we thank all the surgeons and their patients for participating in the study.

1 Bard M, Sutherland AM. Psychological impact of cancer and its treatment. Cancer 1955;8:656-72.

2 Inglis B. The unkindest cut. Guardian 1981 Sept 26:9.

3 Faulder C. Unheard victims of breast cancer. Independent 1986 Oct 7:4

4 Sanger CK, Reznikoff M. A comparison of the psychological effects of breast-saving procedures with the modified radical mastectomy. Cancer 1981;48:2341-6

5 Schain W, Edwards BK, Gorrell CR, et al. Psychosocial and physical outcomes of primary breast cancer therapy: mastectomy vs excisional biopsy and of primary breast cancer therapy: mastectomy vs excisional biop
irradiation. Breast Cancer Research and Treatment 1983;3:377-82.

6 Steinberg MD, Juliano MS, Wise L. Psychological outcome of lumpectomy versus mastectomy in the treatment of breast cancer. Am I Psychiatry 1985:142:34-9.

7 Ashcroft JJ, Leinster SJ, Slade PD. Breast cancer-patient choice of treatment: preliminary communication. $\mathcal{F} R$ Soc Med 1985;78:43-6.

8 De Haes JCJM, van Oostrom MA, Welvaart $K$. The effect of radical and conserving surgery on the quality of life of early breast cancer patients. Eur F Surg Oncol 1986;12:337-42.

9 Bartelink H, van Dam F, van Dongen J. Psychological effects of breast conserving therapy in comparison with radical mastectomy. Int $f$ Radiat Oncol Biol Phys 1985;11:381-5.

10 Fallowfield LJ, Baum M, Maguire GP. Effects of breast conservation on psychological morbidity associated with diagnosis and treatment of early breast cancer. BrMed f 1986:293:1331-4.

11 Lasry JCM, Margolese RG, Poisson R, et al. Depression and body image following mastectomy and lumpectomy. $f$ Chronic Dis 1987;40:529-34.

Wolberg WH, Tanner MA, Romsaas EP, et al. Factors influencing options in primary breast cancer treatment. $\mathcal{F}$ Clin Oncol 1987;5:68-74.

13 Kemeny MM, Wellisch DK, Schains WS. Psychosocial outcome in a randomised surgical trial for treatment of primary breast cancer. Cancer 1988;62:1231-7.

14 Morris J, Royle GT, Taylor I. Changes in the surgical management of early breast cancer in England. $\mathcal{F} R$ Soc Med 1989;82:12-4.

15 Meyer L, Aspergren K. Long term psychological-sequelae of mastectomy and breast conserving treatment for breast cancer. Acta Oncol 1989;28:13-8.

16 Maunsell E, Brisson J, Deschenes L. Psychological distress after initial treatment for breast cancer: a comparison of partial and total mastectomy. f Clin Epidemiol 1989;42:765-71.
17 Wilson RG, Hart A, Dawes PJDK. Mastectomy or conservation: the patient's choice. Br Med J 1988;297:1167-72.

8 Milner PC, Nicholl JP. Effects of breast conservation on psychological morbidity. BrMed f 1986:293:1568.

9 Sims RJ, Tattersall MHN, Coates AS, et al. Randomised comparison of procedures for obtaining informed consent in clinical trials of treatment for cancer. Br Med f 1980;293:1065-8.

20 King J, Nicholson R. Informed consent. Institute of Medical Ethics Bulletin 1986;3(suppl).

21 Baum M, Zilkha K, Houghton J. Ethics of clinical research: lessons for the future. BrMed f 1989;299:251-3.

22 Zigmund AS, Snaith RP. The hospital anxiety and depression scale. Acta Psychiatr Scand 1983;67:361-70.

23 De Haes JCJM, Pruyn JFA, Knippenberg FCE. Klachtenlijst voor kankerpatienten. Eerste ervaringen. Nederlands. Tijdschrift voor de Psychologie 1983;38:403-22.

44 Spielberger CD, Gorsuch RL, Lusherie RE. STAI manual (Form Y). Palo Alto, California: Consulting Psychologists Press, 1983.

25 Wing JK, Cooper JE, Sartorius N. Measurement and classification of psychiatric symptoms. Cambridge: Cambridge University Press, 1974

26 Matthews JNS, Altman DG, Campbell MJ, et al. Analysis of serial measurements in medical research. Br Med f 1990;300:230-5.

27 Cohen J. A coefficient of agreement for nominal scales. Educational and Psychological Measurement 1960;20:37-46.

28 Locker AP, Ellis IO, Morgan DAL, et al. Factors influencing local recurrence after excision and radiotherapy for primary breast cancer. Br $\mathcal{J}$ Surg $1989 \cdot 76 \cdot 890-4$

29 Clements CD, Sider RC. Medical ethics' assault upon medical values. JAMA 1983;250:2011-5.

30 Wagener JJ, Taylor SE. What else could I have done? Patients' responses to failed treatment decisions. Health Psychol 1986;5:481-96.

31 Sutherland HJ, Llewellyn-Thomas HA, Lockwood GA, et al. Cancer patients: their desire for information and participation in treatment decisions. f R Soc Med 1989;82:260-7.

32 Brewin CR, Bradley C. Patient preferences and randomised clinical trials. BrMed f 1989;299:313-5.

33 Fallowfield LJ, Baum M. Psychological welfare of patients with breast cancer. f $R$ Soc Med 1989;82:4-5.

34 Hogbin B, Fallowfield LJ. Getting it taped: the "bad news" consultation with cancer patients. Br f Hosp Med 1989;41:330-3.

35 Fallowfield LJ. Counselling for patients with cancer. Br Med 7 1988;297. 727-8.

36 Levine RJ. Referral of patients with cancer for participation in randomised clinical trials: ethical considerations. $C A$ 1986;36:95-9.

37 Bradford Hill A. Statistical methods in clinical and preventative medicine. New York: Oxford University Press, 1962.

38 Taylor KM, Margolese RG, Soskolne CL. Physicians' reasons for not entering eligible patients into a randomised clinical trial of surgery for breast cancer. NEngl f Med 1984;310:1363-7.

\title{
Long term reduction in sodium balance: possible additional mechanism whereby nifedipine lowers blood pressure
}

\author{
Joe B Pevahouse, Nirmala D Markandu, Francesco P Cappuccio, Martin G Buckley, \\ Giuseppe A Sagnella, Graham A MacGregor
}

Abstract

Objective-To assess the changes in sodium excretion and sodium balance after withdrawal of long term nifedipine.

Design-Single blind, placebo controlled study in patients receiving fixed sodium and potassium intakes.

Setting-Blood pressure unit of a teaching hospital in south London.

Patients-Eight patients with mild to moderate uncomplicated essential hypertension who had been taking nifedipine $20 \mathrm{mg}$ twice daily for at least six weeks.

Interventions-Withdrawal of nifedipine and replacement with matching placebo for one week.

Main outcome measures-Urinary sodium excretion and cumulative sodium balance, body weight, plasma atrial natriuretic peptide concentrations, plasma renin activity and aldosterone concentrations, and blood pressure.

Results-During nifedipine withdrawal there was a significant reduction in urinary sodium excretion (day 1: $-62.7 \mathrm{mmol} / 24 \mathrm{~h} ; 95 \%$ confidence interval -90.3 to -35.0$)$ and each patient retained a mean of 146 (SEM 26) mmol sodium over the week of replacement with placebo. Body weight and plasma atrial natriuretic peptide concentrations increased during the placebo period and seemed to be associated with the amount of sodium retained. Systolic blood pressure rose from 157 (9) to 165 (9) $\mathrm{mm} \mathrm{Hg}(95 \%$ confidence interval of difference $-7 \cdot 1$ to $22 \cdot 1$ ) when nifedipine was replaced with matching placebo, and the rise seemed to be related to the amount of sodium that was retained.

Conclusions-Nifedipine causes a long term reduction in sodium balance in patients with essential hypertension. This long term effect may contribute to the mechanism whereby nifedipine lowers blood pressure.

\section{Introduction}

Nifedipine is now widely used for the treatment of both angina and hypertension. ${ }^{1}$ Its blood pressure lowering effect has been shown to be due to its inhibition of calcium induced contraction of arteriolar smooth muscle, which leads to peripheral vasodilatation. ${ }^{2}$ This effect on arteriolar smooth muscle has been shown to be greater the higher the blood pressure. ${ }^{3}$ An early intravenous study with nifedipine showed that it also caused a natriuresis and diuresis. ${ }^{4}$ Later studies confirmed that acutely nifedipine causes a loss of sodium, which is independent of haemodynamic changes, ${ }^{5.7}$ and one study detected a greater increase in

Correspondence to: 
sodium excretion in patients with hypertension than in normotensive subjects. ${ }^{8}$ It seems to have been generally assumed, however, that this acute effect of nifedipine on sodium excretion does not result in any long term reduction in sodium balance.

There are considerable difficulties in measuring long term changes in sodium balance as the small reduction in total body sodium or exchangeable sodium that might have occurred is difficult to detect with currently available methods. Nevertheless, if nifedipine does cause a reduction in sodium balance and treatment with nifedipine is then stopped retention of sodium should occur.

We decided to study patients with essential hypertension who had been receiving long term treatment with nifedipine and look at the changes in sodium balance that occurred when the nifedipine was discontinued.

\section{Patients and methods}

Patients with essential hypertension referred to the blood pressure unit by local general practitioners were included in the study if no underlying cause for their high blood pressure had been found. Patients with renal failure (plasma creatinine concentration greater than $140 \mu \mathrm{mol} / \mathrm{l}$ ), ischaemic heart disease, or cerebrovascular disease or who were taking a contraceptive pill were excluded. The protocol was approved by the local ethical committee.

Eight patients who gave informed consent entered and completed the study. They were recruited on the basis of their willingness to adhere to a prolonged period (18 days) of controlled and fixed sodium and potassium intake and to undergo metabolic investigations including daily 24 hour urine collections. There were four men and four women (five white, three black) and their mean age was 59 years (range 31 74). All patients had been taking nifedipine (Adalat Retard $20 \mathrm{mg}$ twice daily) for at least six weeks before the study. Their average blood pressure before treatment had been 186/107 (SD 19/12) $\mathrm{mm} \mathrm{Hg}$. The median duration of nifedipine treatment was 31.5 weeks (range 6-234). All patients continued with nifedipine for a further month, observation being made every two weeks. Their average supine blood pressure at entry to the study and while still taking nifedipine was $157 / 92 \mathrm{~mm} \mathrm{Hg}$. At the end of the run in observation period each patient was placed on a constant diet provided by the metabolic ward kitchen which contained $150 \mathrm{mmol}$ sodium and $80 \mathrm{mmol}$ potassium daily. Patients took the diet throughout. During the study each patient was closely supervised as an outpatient. After 11 days of taking the control diet patients had the nifedipine stopped and replaced with matching placebo tablets twice daily in a single blind fashion for seven days while continuing with the diet. Throughout the study patients were allowed to go about their normal activities but were discouraged from vigorous exercise. They were not admitted to hospital.

Patients were seen in the blood pressure unit at the same time of day, by the same nurse, in the same room.
Blood pressure was measured on the same arm between $10 \mathrm{am}$ and noon with a semiautomatic ultrasound sphygmomanometer (Arteriosonde) ${ }^{9}$ with attached recorder. The measurements were therefore free of observer bias. Supine and standing blood pressures were taken as the means of five readings at one to two minute intervals with the patient in each position. Supine blood pressure was measured before standing blood pressure. Pulse rate was measured with a Cambridge 3048 pulse monitor. Body weight was recorded in the morning after voiding, the patients wearing indoor clothing and no shoes.

Daily 24 hour urine collections were obtained throughout the study for measurements of volume and sodium, potassium, and creatinine concentrations. Urinary electrolyte values were measured by flame photometry. Fasting venous blood was sampled without stasis after the patient had been sitting upright for 10 minutes. Samples were taken between $10 \mathrm{am}$ and noon on day -3 of the control period while the patient was taking nifedipine and on days 1,3 , and 5 of the placebo period. Variables measured were plasma electrolyte, urea, and creatinine concentrations; packed cell volume; total protein concentration; plasma renin activity ${ }^{10}$; and plasma aldosterone $\mathrm{e}^{11}$ and atrial natriuretic peptide concentrations. ${ }^{12}$

All results are given as means and SEM or $95 \%$ confidence intervals. Sodium balance was calculated as the cumulative sum of the differences between the average urinary sodium excretion during the last four days of the control period while taking nifedipine and the daily urinary sodium excretion while taking placebo.

Test for homogeneity of variance, repeated measurements analysis of variance, and Student's $t$ test for paired observations were used for the statistical analysis ${ }^{13}$ with the statistical package for the social sciences. $^{14}$

\section{Results}

During the control period with nifedipine and the controlled diet urinary sodium excretion was stable (table I) with an average value of $138(5) \mathrm{mmol} / 24 \mathrm{~h}$ over the last four days. When nifedipine was stopped and replaced with matching placebo for seven days there was a significant fall in urinary sodium excretion as compared with the control period with nifedipine $\left(F_{10,70}=5 \cdot 1 ; p<0.001\right)$ (table I, fig 1). On day 1 of the placebo period urinary sodium excretion fell to 75 (9) $\mathrm{mmol} / 24 \mathrm{~h} \quad(-62.7 \mathrm{mmol} / 24 \mathrm{~h} ; 95 \%$ confidence interval -90.3 to -35.0$)(\mathrm{p}<0.001)$ (tables I and II). A similar pattern was observed for the urinary volume $\left(F_{10,70}=2 \cdot 4 ; p<0.02\right)$ (tables I and II, fig 1). Average urinary volume during treatment with nifedipine was $1.57(0 \cdot 14) 1 / 24 \mathrm{~h}$ over the last four days and significantly decreased when nifedipine was stopped and replaced with matching placebo $(-0.411 / 24 \mathrm{~h}$; $95 \%$ confidence interval -0.81 to -0.01 ) (table II). While taking placebo all patients were in positive sodium balance (fig 2). During the seven days on placebo each patient retained on average $146(26) \mathrm{mmol}$ sodium over the entire period $\left(\mathrm{F}_{10,70}=21.4 ; \mathrm{p}<0.001\right)$

TABLE I-Mean (SEM) urinary sodium, potassium, and creatinine concentrations, urinary volume, and cumulative sodium balance during long term nifedipine treatment and after withdrawal in eight patients with essential hypertension receiving fixed sodium (150 mmol/day) and potassium ( 80 mmol/day) intakes

\begin{tabular}{|c|c|c|c|c|c|c|c|c|c|c|c|}
\hline & \multicolumn{4}{|c|}{ Nifedipine } & \multicolumn{7}{|c|}{ Placebo } \\
\hline & Day -4 & Day -3 & Day -2 & Day -1 & Day 1 & Day 2 & Day 3 & Day 4 & Day 5 & Day 6 & Day 7 \\
\hline Urinary sodium $(\mathrm{mmol} / 24 \mathrm{~h})$ & $133(10)$ & $141(10)$ & $139(10)$ & $139(12)$ & $75(9)_{\star \star \star \star}$ & $106(11)^{\star}$ & $123(8)^{\star}$ & $121(6)^{\star}$ & $127(9)$ & $144(6)$ & $121(12)$ \\
\hline Urinary potassium $(\mathrm{mmol} / 24 \mathrm{~h})$ & $63(6)$ & $61(4)$ & $54(5)$ & $60(5)$ & $55(3)$ & $63(6)$ & $64(5)$ & $61(3)$ & $60(5)$ & $68(7)$ & $64(4)$ \\
\hline Urinary creatinine (mmol/24 h) & $12 \cdot 3(1 \cdot 4)$ & $12 \cdot 1(0 \cdot 4)$ & $11 \cdot 5(0 \cdot 5)$ & $12 \cdot 2(0 \cdot 9)$ & $11 \cdot 4(0 \cdot 8)$ & $11 \cdot 5(0.9)$ & $11 \cdot 9(0 \cdot 6)$ & $12 \cdot 8(0.9)$ & $11 \cdot 7(0 \cdot 5)$ & $12 \cdot 5(0 \cdot 5)$ & $12 \cdot 3(1 \cdot 0)$ \\
\hline Urinary volume $(1 / 24 \mathrm{~h})$ & $1.51(0 \cdot 17)$ & $1.43(0 \cdot 12)$ & $1.65(0.20)$ & $1.68(0 \cdot 19)$ & $1 \cdot 16(0 \cdot 12)$ & * $1 \cdot 29(0 \cdot 13)^{\star \star}$ & $1.43(0 \cdot 14)$ & $1.42(0.12)$ & $1 \cdot 37(0 \cdot 10)$ & $1.55(0 \cdot 10)$ & $1.57(0.18)$ \\
\hline Cumulative sodium balance $(\mathrm{mmol})$ & $4.9(6.8)$ & $2 \cdot 1(8 \cdot 2)$ & $1 \cdot 3(6 \cdot 9)$ & 0 & $62 \cdot 7(11 \cdot 7)^{\star}$ & $94.2(16.9)^{\star \star \star}$ & $109 \cdot 3(13 \cdot 5)^{\star \star}$ & $25 \cdot 7(12 \cdot 0)^{\star \star}$ & $136 \cdot 3(16 \cdot 6)^{\star \star}$ & $129 \cdot 6(22 \cdot 2)^{\star \star}$ & $146 \cdot 2(25 \cdot 8)^{\star \star \star}$ \\
\hline
\end{tabular}

${ }^{\star} \mathrm{p}<0.05, \star \star \mathrm{p}<0.01, \star \star \star \mathrm{p}<0.001$. Compared with mean value during last four days of nifedipine treatment (paired $t$ test)

One way analysis of variance for repeated measurements: urinary sodium $F_{10,70}=5 \cdot 1, p<0 \cdot 001$; urinary volume $F_{10,70}=2 \cdot 4, p=0 \cdot 016 ;$ cumulative sodium balance $F_{10,70}=21 \cdot 4, p<0 \cdot 001$. 
(table I, fig 3). No change was detected in either urinary potassium excretion or urinary creatinine excretion during the study (table I).

The mean plasma concentration of atrial natriuretic peptide during the control period with nifedipine (day -3) was $13.2(1 \cdot 3) \mathrm{ng} / \mathrm{l}$. When nifedipine was discontinued and replaced with placebo the plasma concentration increased to $21 \cdot 0(2 \cdot 3) \mathrm{ng} / \mathrm{l}$ by the fifth day $(\mathrm{p}<0.01)$ (fig 3). The increase in the plasma concentrations of atrial natriuretic peptide paralleled the increase in the amount of sodium retained after nifedipine withdrawal (fig 3). Associated with the sodium retention there was an average increase in body weight of $0.8 \mathrm{~kg}\left(\mathrm{~F}_{10,70}=2.7 ; \mathrm{p}=0.025\right)$ and a fall in both total protein concentration and packed cell volume (table III). Hence changes in indirect indices of extracellular volume expansion were related to the amount of sodium retained when nifedipine was withdrawn.

Both plasma renin activity and the plasma aldosterone concentration tended to decrease by the end of the placebo period (fig 4), but the changes were not significant.

During the placebo period supine blood pressure rose whereas pulse rate fell (table III), although the differences did not reach significance. The rise in

TABLE II-Mean differences (95\% confidence intervals) in urinary sodium excretion and urinary volume during nifedipine withdrawal as compared with mean values during last four days of nifedipine treatment in eight patients with essential hypertension receiving fixed sodium ( $150 \mathrm{mmol} /$ day) and potassium ( $80 \mathrm{mmol} /$ day) intakes

\begin{tabular}{|c|c|c|}
\hline Day & Urinary sodium $(\mathrm{mmol} / 24 \mathrm{~h})$ & Urinary volume $(1 / 24 \mathrm{~h})$ \\
\hline $\begin{array}{l}1 \\
2 \\
3 \\
4 \\
5 \\
6 \\
7\end{array}$ & $\begin{array}{l}-62 \cdot 7(-90 \cdot 3 \text { to }-35 \cdot 0) \\
-31 \cdot 6(-54 \cdot 3 \text { to }-8 \cdot 8) \\
-15 \cdot 1(-28 \cdot 4 \text { to }-1 \cdot 7) \\
-16 \cdot 4(-27 \cdot 9 \text { to }-5 \cdot 0) \\
-10 \cdot 6(-28 \cdot 8 \text { to } 7 \cdot 7) \\
6 \cdot 7(-14 \cdot 4 \text { to } 27 \cdot 8) \\
-16 \cdot 6(-43 \cdot 1 \text { to } 10 \cdot 0)\end{array}$ & $\begin{array}{l}-0.41(-0.81 \text { to }-0.01) \\
-0.28(-0.40 \text { to }-0.16) \\
-0.14(-0.45 \text { to } 0.17) \\
-0.14(-0.34 \text { to } 0.05) \\
-0.20(-0.42 \text { to } 0.02) \\
-0.02(-0.18 \text { to } 0.14) \\
-0.01(-0.32 \text { to } 0.32)\end{array}$ \\
\hline
\end{tabular}
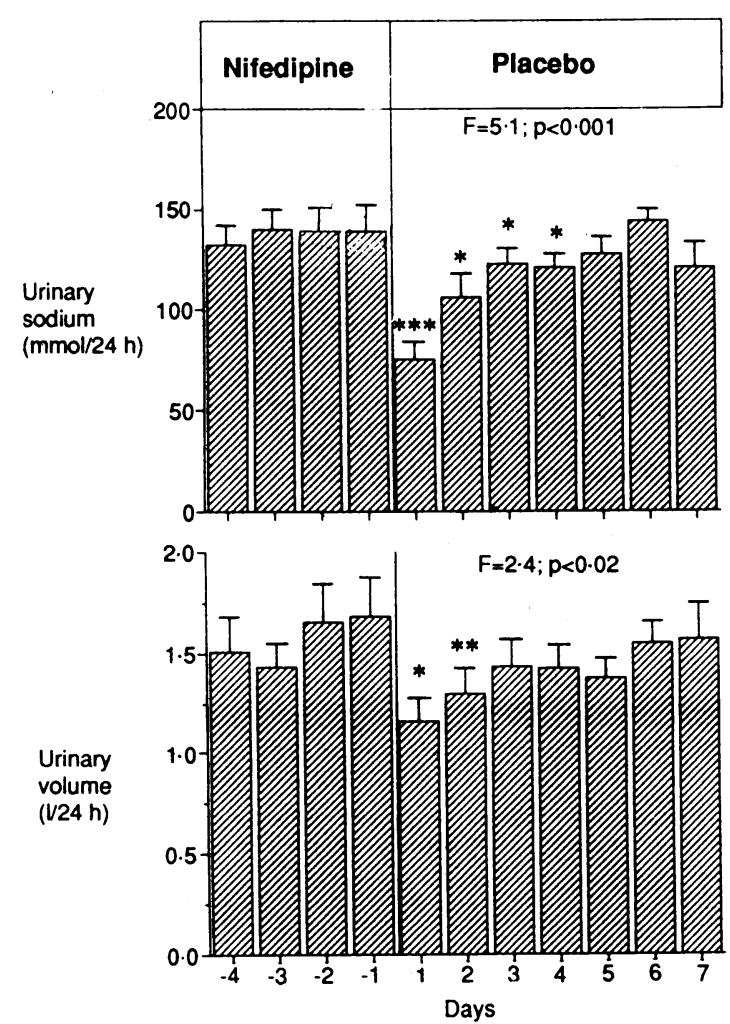

FIG 1-Mean urinary sodium excretion values and urinary volumes during long term nifedipine treatment and after withdrawal in eight patients with essential hypertension receiving fixed sodium (150 mmol/ day) and potassium ( 80 mmol/day) intakes. Bars are SEM. $\left({ }^{\star} p<0.05\right.$, $\star \star p<0.01, \star \star \star p<0.001$ Compared with mean value during last four days of nifedipine treatment)

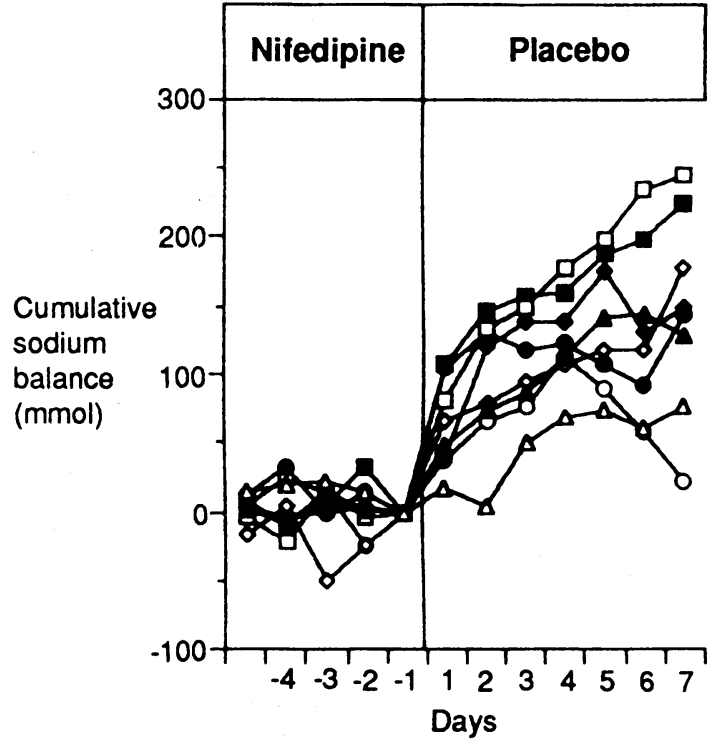

FIG 2-Individual plots of cumulative sodium balance during lon term nifedipine treatment and after withdrawal in eight patients with essential hypertension receiving fixed sodium ( $150 \mathrm{mmol} /$ day) and potassium ( $80 \mathrm{mmol} /$ day) intakes
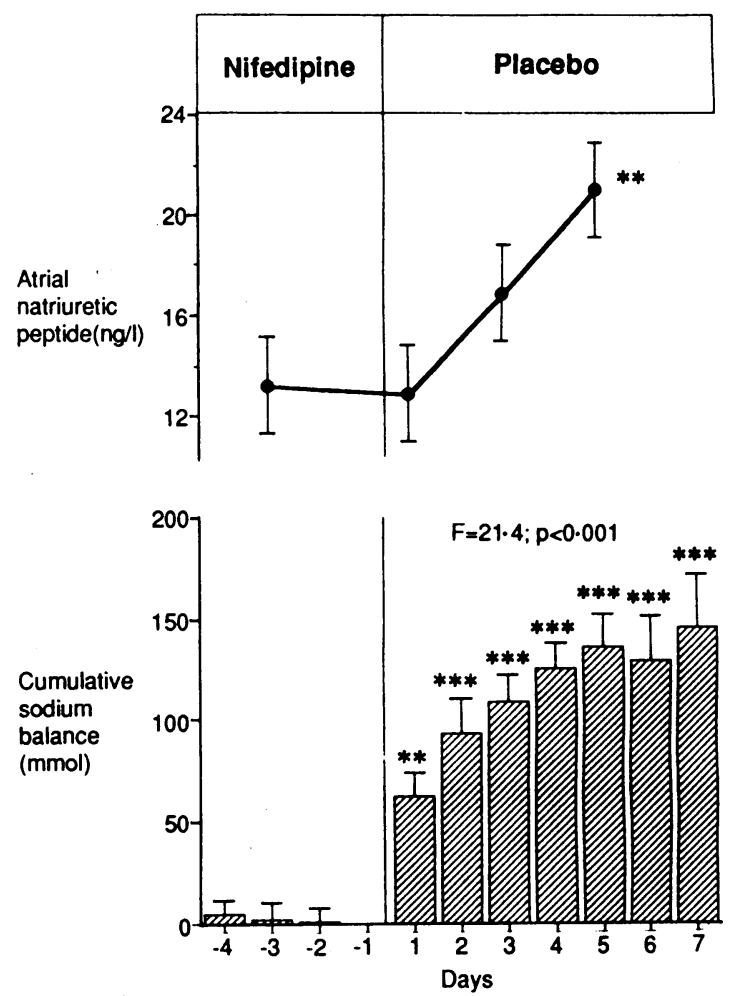

FIG 3-Mean plasma atrial natriuretic peptide and cumulative sodium balance values during long term nifedipine treatment and after withdrawal in eight patients with essential hypertension receiving fixed sodium ( $150 \mathrm{mmol} / \mathrm{day})$ and potassium $(80 \mathrm{mmol} / \mathrm{day})$ intakes. Bars are SEM. $(\star \star p<0.01, \star \star \star p<0.001$ Compared with mean value during last four days of nifedipine treatment)

systolic blood pressure also seemed to parallel the amount of sodium retained after nifedipine withdrawal whereas the change in diastolic blood pressure did not.

No change was detected in plasma electrolyte, urea, and creatinine concentrations during the study (data not shown).

\section{Discussion}

This study clearly shows that in a group of patients with essential hypertension receiving long term nifedipine withdrawal of the nifedipine causes a significant reduction in urinary sodium excretion and a positive sodium balance. This sodium retention is accompanied 


\begin{tabular}{|c|c|c|c|c|c|c|c|}
\hline & \multirow[b]{3}{*}{$\begin{array}{l}\text { Mean (SEM) during last } \\
\text { four days of nifedipine }\end{array}$} & \multicolumn{6}{|c|}{ Placebo } \\
\hline & & \multicolumn{2}{|r|}{ Day 1} & \multicolumn{2}{|r|}{ Day 3} & \multicolumn{2}{|r|}{ Day 5} \\
\hline & & Mean (SEM) & $\begin{array}{c}\text { Mean difference } \\
\text { (95\% confidence interval) }\end{array}$ & Mean (SEM) & $\begin{array}{c}\text { Mean difference } \\
\text { (95\% confidence interval) }\end{array}$ & Mean (SEM) & $\begin{array}{c}\text { Mean difference } \\
\text { (95\% confidence interval) }\end{array}$ \\
\hline Systolic blood pressure $(\mathrm{mm} \mathrm{Hg})$ & $157 \cdot 5(8 \cdot 8)$ & $160 \cdot 1(5 \cdot 9)$ & $2 \cdot 6(-12 \cdot 9$ to $18 \cdot 2)$ & $162 \cdot 2(8 \cdot 1)$ & $4 \cdot 7(-4 \cdot 2$ to $13 \cdot 7)$ & $165 \cdot 0(8 \cdot 6)$ & $7 \cdot 5(-7 \cdot 1$ to $22 \cdot 1)$ \\
\hline Diastolic blood pressure $(\mathrm{mm} \mathrm{Hg})$ & $92 \cdot 0(2 \cdot 6)$ & $93.4(1.8)$ & $1.4(-4.9$ to $7 \cdot 6)$ & $92 \cdot 0(2 \cdot 7)$ & $0(-6 \cdot 1$ to $6 \cdot 1)$ & $94 \cdot 1(2 \cdot 5)$ & $2 \cdot 1(-7 \cdot 8$ to $12 \cdot 0)$ \\
\hline Pulse rate (beats/min) & $79 \cdot 6(4 \cdot 0)$ & $78 \cdot 0(4 \cdot 7)$ & $-1.6(-6.7$ to $3 \cdot 5)$ & $75 \cdot 5(4 \cdot 0)$ & $-4 \cdot 1(-9 \cdot 2$ to $1 \cdot 0)$ & $76 \cdot 4(5 \cdot 2)$ & $-3 \cdot 2(-8.9$ to $2 \cdot 4)$ \\
\hline Body weight $(\mathrm{kg})$ & $68 \cdot 4(2 \cdot 3)$ & $68 \cdot 6(2 \cdot 2)$ & $-0.2(-1.0$ to 1.4$)$ & $69 \cdot 2(2 \cdot 3)$ & $0.8(-0.2$ to 1.8$)$ & $69 \cdot 2(2 \cdot 2)^{\star}$ & $0.7(0$ to 1.6$)$ \\
\hline Packed cell volume & $0.41(0.02)$ & $0.40(0.02)$ & $-0.01(-0.03$ to 0.01$)$ & $0.38(0.02)$ & $-0.02(-0.04$ to 0.01$)$ & $0.38(0.02)^{\star \star \star}$ & $-0.02(-0.05$ to -0.01$)$ \\
\hline Total protein $(\mathrm{g} / \mathrm{l})$ & $75(2)$ & $74(1)$ & $-0.6(-3.4$ to $2 \cdot 3)$ & $72(1)^{\star}$ & $-3 \cdot 0(-5 \cdot 7$ to -0.3$)$ & $70(3)$ & $-5 \cdot 3(-11 \cdot 5$ to $1 \cdot 0)$ \\
\hline
\end{tabular}

$p<0.05, \star \star \star p<0.001$ Compared with value during last four days of nifedipine treatment.

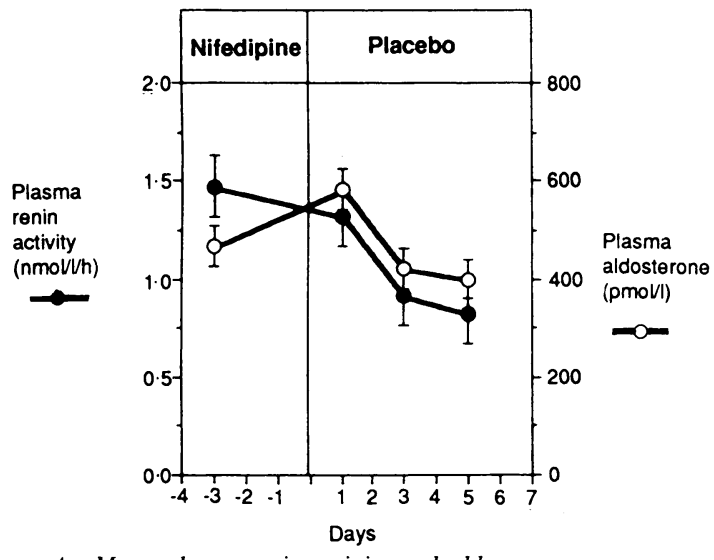

FIG 4-Mean plasma renin activity and aldosterone measurements during long term nifedipine treatment and after withdrawal in eight patients with essential hypertension receiving fixed sodium $(150 \mathrm{mmol}$ day) and potassium ( $80 \mathrm{mmol} /$ day) intakes. Bars are SEM

by a parallel increase in both body weight and plasma atrial natriuretic peptide concentration and by a parallel decrease in packed cell volume and total protein concentration, which are likely to be due to expansion of extracellular volume. Furthermore, the amount of sodium that was retained when nifedipine was stopped seemed to be similar in magnitude to the amount of sodium that was lost in the acute studies in which nifedipine was given. ${ }^{8}$ These findings taken together strongly suggest that the acute loss of sodium that occurs when nifedipine is started is maintained in the long term and that when nifedipine is stopped the same amount of sodium is retained as was lost initially.

The mechanisms responsible for the natriuresis which occurs with nifedipine are not clear. Renal micropuncture studies in animals suggest that a direct tubular effect of dihydropiridines may be responsible for the natriuresis recorded after acute administration ${ }^{15}$ in the absence of changes in the glomerular filtration rate and renal blood flow. Similar studies looking at the longer term effect on sodium and water excretion have not been carried out, however, and it is not known whether these tubular effects may also be responsible for the prolonged natriuretic effect. One study in humans employing the lithium clearance method for assessing proximal and distal tubular sodium reabsorption failed to detect any significant change in either plasma or extracellular fluid volume during prolonged nifedipine treatment. ${ }^{16}$ Nevertheless, a small reduction in total body or exchangeable sodium would have been difficult to detect with the methods used. Furthermore, in that study the finding of enhanced proximal sodium reabsorption in the absence of changes in both distal and total sodium excretion supports the view of nifedipine being associated with a negative sodium balance and consequent changes in kidney tubular function partly resembling those found during long term treatment with diuretics. ${ }^{17}$

It is likely that the reduction in sodium balance that occurs with long term nifedipine contributes along with the arteriolar vasodilatation to the mechanism whereby nifedipine lowers blood pressure. The reduction in sodium balance may in part help to explain why the blood pressure lowering effect of nifedipine is not blunted by a high sodium intake ${ }^{18-19}$ and, conversely, is not enhanced by adding a thiazide diuretic..$^{20-22}$ It is also possible that if nifedipine has the same effect on sodium balance in patients with ischaemic heart disease the loss of sodium that may occur may also act as an additional mechanism along with the vasodilatation to offset any negative inotropic effect that nifedipine may have directly on heart muscle.

Paradoxically, some patients when treated with nifedipine develop oedema in the legs. This oedema does not seem to be mediated by sodium and water retention but is thought to be related to a change in capillary haemodynamics with increased filtration of fluid, particularly on standing. ${ }^{23}$ Interestingly in this regard anecdotal reports suggest that this oedema is not sensitive to either diuretics or salt restriction.

Thiazide diuretics also cause a long term reduction in sodium balance. The $150 \mathrm{mmol}$ loss of sodium with nifedipine is probably similar to the sodium loss seen with a thiazide diuretic. In contrast with thiazide diuretics, however, nifedipine does not seem to have any deleterious metabolic effects. Possibly our results might enhance further interest in the mechanisms concerned as if this is a direct tubular effect mediated by a specific receptor it is possible that more selective drugs might be developed that could act as "diuretics" without metabolic effects.

1 MacGregor GA. Hypertension. In: Krebs R, ed. Treatment of cardiovascular diseases by Adalat. New York: Schattauer, 1986:231-58.

2 Fleckenstein A. History of calcium antagonists. Clin Res 1983;52 (suppl 1):316.

3 Robinson BF. Altered calcium handling as a cause of primary hypertension. f Hypertens 1984;2:453-60.

4 Yokoyama S, Kaburagi T. Clinical effects of intravenous nifedipine on renal function. $\mathcal{f}$ Cardiovasc Pharmacol 1983;5:67-71.

5 Ene HD, Williamson PJ, Roberts CJC, Waddel G. The natriuresis following oral administration of the calcium antagonists, nifedipine and nitrendipine. Brf Clin Pharmacol 1985;19:423-7.

6 Zanchetti A, Stella A, Golin A. Adrenergic sodium handling and the natriuretic action of calcium antagonists. I Cardiovasc Pharmacol 1985;7 (suppl 6): 194-8

7 Luft FC, Aronoff GR, Sloan RS, Fineberg NS, Weinberger MH. Calcium channel blockade with nitrendipine. Effects on sodium homeostasis, the renin-angiotensin system and the sympathetic nervous system in humans. Hypertension 1986;7:438-42.

8 Leonetti G, Cuspidi C, Sampieri L, Terzoli L, Zanchetti A. Comparison of cardiovascular, renal and humoral effects of acute administration of two calcium channel blockers in normotensive and hypertensive subjects. f Cardiovasc Pharmacol 1982;4(suppl 3):319-24.

9 George CF, Lewis PJ, Petrie A. Clinical experience with use of ultrasound sphygmomanometer. Br Heart f 1975;37:804-7.

10 Roulston JE, MacGregor GA. Measurements of plasma renin activity by radioimmunoassay after prolonged cold storage. Clin Chim Acta 1978;88. 45-8

11 James VHT, Wilson GA. Determination of aldosterone in biological fluids. In: Reid E, ed. Assay of drugs and other trace compounds in biological fluids. Methodological development in biochemistry. Vol 5. Amsterdam: Elsevier, 1976:149-58

12 Sagnella GA, Markandu ND, Shore AC, MacGregor GA. Effects of changes in dietary sodium intake and saline infusion on immunoreactive atrial natriuretic peptide in human plasma. Lancet 1985;ii:1208-11.

13 Snedecor GW, Cochran WG. Statistical methods. Ames, Iowa: Iowa State University Press, 1980.

14 SPSS Inc. SPSS` user's guide. New York: McGraw Hill, 1983. 
15 Di Bona GF, Sawin LL. Renal tubular site of action of felodipine. F Pharmacol Exp Ther 1984;223:420-4.

16 Bruun NE, Ibsen H, Skoot P, Toftdahl D, Giese J, Holstein-Rathlou NH. Lithium clearance and renal tubular sodium handling during acute and lon 13.

17 Petersen V, Hvidt S, Thomsen K, Schou M. Effect of prolonged thiazide treatment on renal lithium clearance. Br Med f 1974; iii: 143-5.

18 Cappuccio FP, Markandu ND, MacGregor GA. Calcium antagonists an sodium balance. Effect of changes in sodium intake and of the addition of a thiazide diuretic on the blood pressure lowering effect of nifedipine. Thiazide diuretic on the blood pressure lowering

9 MacGregor GA, Cappuccio FP, Markandu ND. Sodium intake, high blood pressure and calcium channel blockers. Am f Med 1987;82(suppl 3B):16-22

20 Cappuccio FP, Markandu ND, Tucker F, Sagnella GA, MacGregor GA. Does a diuretic cause a further fall in blood pressure in hypertensive patients already on nifedipine? Fournal of Clinical Hypertension 1986;4:346-53.

21 Cappuccio FP, Markandu ND, Tucker F, Shore AC MacGregor GA A double-blind study of the blood pressure lowering effect of a thizide diuretic in hypertensive patients already on nifedipine and a betalock diuretic in hypertensive $p$

22 Salvetti A Magagna A, Innocenti P, et al. Chlorthalidone does not increase the hypotensive effect of nifedipine in essential hypertensives: a crossover multicentre study. $f$ Hypertens 1989:7(suppl 6):250-1.

23 Williams SA, Rayman G, Tooke JE. Oedema caused by vasodilator therapy: evidence for impairment of posturally-induced vasoconstriction [Abstract] Int $\mathcal{J}$ Microcirc Clin Exp 1986;5:393.

(Accepted 18 fuly 1990)

\title{
Lipid screening: Is it enough to measure total cholesterol concentration?"
}

\author{
H A WLeil, DLMant, L/Jones, BLMorgan, J ILMann
}

\begin{abstract}
Objectives-To determine whether measurement of total cholesterol concentration is sufficient to identify most patients at lipoprotein mediated risk of coronary heart disease without measurement of triglyceride and high density lipoprotein (HDL) cholesterol concentrations.
\end{abstract}

Design-Cross sectional screening programme.

Setting-Six general practices in Oxfordshire.

Patients-1901 Men and 2068 women aged 25-59.

Main outcome measure-Cardiovascular risk as assessed by fasting venous plasma concentrations of total cholesterol, triglyceride, and HDL cholesterol.

Results-2931 Patients (74\% of those screened) had a total cholesterol concentration of $<6.5 \mathrm{mmol} / 1$. If the triglyceride concentration had not been measured in these patients isolated hypertriglyceridaemia ( $\geqslant 2.3 \mathrm{mmol} / \mathrm{l}$ ) would have remained undetected in 185. Among these 185 patients, however, 123 were overweight or obese and only 18 $(0.6 \%$ of those screened) had an increased risk associated with both a raised triglyceride concentration ( $\geqslant 2.3 \mathrm{mmol} / \mathrm{l}$ ) and a low HDL cholesterol concentration $(<0.9 \mathrm{mmol} / \mathrm{l})$. Conversely, in the 790 patients with predominant hypercholesterolaemia (cholesterol concentration $\geqslant 6.5 \mathrm{mmol} / \mathrm{l}$ and triglyceride concentration $<2.3 \mathrm{mmol} / \mathrm{l}$ ) measurement of HDL cholesterol concentration showed that 348 (9\% of those screened) had only a moderately increased risk with a ratio of total to HDL cholesterol of $<4.5$ and 104 had a low risk with a ratio of $<3.5$.

Conclusions-Fasting triglyceride and HDL cholesterol concentrations identify few patients at increased risk of coronary heart disease if the total cholesterol concentration is less than $6.5 \mathrm{mmol} / \mathrm{l}$. HDL cholesterol and triglyceride concentrations should, however, be measured in patients with a total cholesterol concentration exceeding this value. Total cholesterol concentration alone may overestimate risk in a considerable number of these patients, and measurement of HDL cholesterol concentration allows a more precise estimate of risk. Measurement of the triglyceride concentration is required to characterise the lipoprotein abnormality. A patient should not be started on a drug that lowers lipid concentrations without having had a full lipoprotein assessment including measurement of HDL cholesterol concentration.

University of Otago,

Dunedin, New Zealand

J I Mann, DM, professor of

human nutrition

Correspondence to: Dr Neil.
Introduction

Hypercholesterolaemia is a major and modifiable risk factor for coronary heart disease. Both dietary and drug treatment can reduce morbidity and mortality from cardiovascular disease, ${ }^{1-4}$ and several policy statements have provided practical guidelines for the management of hyperlipidaemias. The most widely adopted guidelines in the United Kingdom are those of the European Atherosclerosis Study Group 5 and the British Hyperlipidaemia Association. ${ }^{6}$ Although these take account of high density lipoprotein (HDL) cholesterol and triglyceride concentrations in making recommendations for treatment, they do not specifically recommend any measurement other than that of total cholesterol concentration for screening.

Various protocols are used in practice; some are restricted to random measurement of cholesterol concentration, others include measurement of fasting triglyceride concentrations, and some also include measurement of HDL cholesterol concentrations. These differences reflect the limitations of the available data. The evidence for hypertriglyceridaemia as an independent risk factor for coronary heart disease is much less well established than that for hypercholesterolaemia, ${ }^{78}$ but the Framingham study suggests that the risk of coronary heart disease is increased in people with normal cholesterol concentrations, high triglyceride concentrations, and low HDL cholesterol concentrations. ${ }^{9}$ It is therefore important to know how many patients at high risk might be missed if measurements of HDL cholesterol and triglyceride concentrations were restricted to patients with a total cholesterol concentration exceeding a predetermined value. A concentration of $6.2 \mathrm{mmol} / 1$ is used in the United States, ${ }^{10}$ and $6.5 \mathrm{mmol} / 1$ has been suggested in the United Kingdom. ${ }^{11}$ As prospective studies have shown an inverse relation between plasma concentrations of HDL cholesterol and the incidence of coronary heart disease $^{31213}$ it is also important to know what proportion of patients with raised total cholesterol concentrations can be shown by measurement of the HDL cholesterol concentration to be at little or no excess risk of coronary heart disease.

Our aim was to determine the extent of the misclassification of the risk of coronary heart disease associated with a lipid screening protocol that measures only total cholesterol concentration.

\section{Patients and methods}

Six general practices in Oxfordshire participated in the study, which was part of a larger survey of the distribution of plasma lipid concentrations and prevalence of other risk factors for cardiovascular disease. ${ }^{14}$ Altogether 1912 men and 2094 women aged 25-59 were recruited either opportunistically when 